\title{
Pengaruh Pendekatan Child Healthcare Model dan Transtheoretical Model terhadap Asupan Makan Anak Overweight dan Obesitas
}

\author{
The Effect of Child Healthcare Model and Transtheoretical Model \\ Approaches to Food Intake of Overweight and Obese Children
}

\author{
Kadek Ayu Erika* Elly Nurachmah**
}

\begin{abstract}
*Departemen Anak Program Studi Ilmu Keperawatan Fakultas Kedokteran Universitas Hasanuddin, **Program Pascasarjana Fakultas Ilmu Keperawatan Universitas Indonesia
\end{abstract}

\begin{abstract}
Abstrak
Overweight dan obesitas pada anak merupakan suatu masalah yang kompleks disebabkan multifaktor, yaitu interaksi genetik dan lingkungan. Gaya hidup perkotaan dipicu oleh asupan makanan yang berlebih pada anak overweight dan obesitas. Strategi untuk menurunkan asupan makan berlebih pada anak adalah dengan pendekatan child healthcare model dan transtheoretical model sehingga dapat mengendalikan gaya hidup anak. Penelitian ini bertujuan membuktikan pengaruh pendekatan child healthcare dan transtheoretical model terhadap asupan karbohidrat anak overweight dan obesitas. Penelitian ini dilaksanakan di wilayah kecamatan Biringkanaya dan Tamalanrea, Makassar, pada bulan Agustus 2013 sampai Maret 2014. Desain yang digunakan adalah quasy experiment yaitu pre test and posttest with control group design. Sampel dipilih secara purposive sebanyak 31 anak overweight atau obesitas pada kelompok perlakuan dan 33 kontrol pada anak sekolah dasar kelas 4 - 6 . Intervensi penelitian 6 bulan dengan pemberian buku panduan gaya hidup sehat. Instrumen menggunakan kuesioner food recall. Hasil uji-t berpasangan menghasilkan asupan karbohidrat pada pre-post intervensi kelompok perlakuan dengan nilai p $0,004(<0,05)$ sedangkan kelompok kontrol dengan nilai p 0,114. Penelitian ini menyimpulkan bahwa ada pengaruh pendekatan child healthcare model dan transtheoretical model terhadap asupan karbohidrat anak overweight dan obesitas.
\end{abstract}

Kata kunci: Asupan makan, child healthcare model, obesitas, overweight, transtheoretical model

\section{Abstract}

Overweight and obesity in children is a complex problem that is caused by a multifactorial genetic and environmental interactions. Urban lifestyle fueled by excessive food intake in overweight and obese children. Strategies to reduce excessive food intake in children is the child healthcare approach and the transtheoretical model so that the model can control the child's lifestyle. This study aimed to prove the effect of child healthcare approach and the transtheoretical model of the food intake of overweight and obese children. This research was conducted in the district area Tamalanrea and Biringkanaya, Makassar from August 2013 to March 2014. The design used is quasy experiment pretest and posttest with control group design. Purposively selected sample of 31 children as overweight or obese in the treatment group and 33 controls on primary school children grade 4 - 6 . Intervention research was conducted during a six month period by providing guide books on healthy lifestyle. The instrument used food recall questionnaire. Paired t-test results produced carbohydrate intake in the pre-post intervention treatment groups with $p$ value $0.004(<0.05)$, whereas the control group with $p$ value of 0.114 . This study concludes that there is influence of CHM and TTM approaches to the intake of carbohydrates of overweight and obese children.

Keywords: Food intake, child healthcare model, obesity, overweight, transtheoretical model

\section{Pendahuluan}

Overweight dan obesitas sekarang merupakan peringkat kelima sebagai risiko global untuk terjadinya kematian. Prevalensi overweight dan obesitas pada anak diperkirakan 35 juta terdapat di negara berkembang dibandingkan dengan 8 juta yang ada di negara maju. ${ }^{1}$ Berdasarkan The National Youth Risk Behaviour Survey (YRBS) tahun 1999 - 2011 pada anak sekolah umur 9 12 tahun, prevalensi obesitas mengalami peningkatan dari $10,6 \%$ menjadi $13 \%$ sedangkan overweight juga meningkat dari $14,2 \%$ menjadi $15,2 \% .^{2}$ Obesitas merupakan masalah yang sedang terjadi di negara berkem-

Korespondensi: Kadek Ayu Erika, Program Studi Ilmu Keperawatan FK Universitas Hasanuddin, Kampus Unhas Tamalanrea Jl. Perintis Kemerdekaan Km.10 Makassar, Hp.081342129855,e-mail:kadek20_uh@yahoo.com 
bang termasuk Indonesia. Sekelompok masyarakat Indonesia terutama di kota-kota besar mengalami masalah kesehatan masyarakat utama justru dipicu dengan adanya kelebihan gizi dan aktivitas yang kurang pada masa kanak-kanak.3,4

Perubahan gaya hidup yang cepat termasuk pola makan dan aktivitas telah menyebabkan peningkatan prevalensi anak obesitas (5 - 19 thn) di negara berkembang. Prevalensi obesitas pada anak usia 5 - 19 tahun mengalami peningkatan dari tahun 1999 - 2004 di Indonesia yaitu pada obesitas dari 5,3\% menjadi 8,6\% sedangkan overweight, dari 2,7\% menjadi 3,7\%.5 Berdasarkan Riset Kesehatan Dasar (Riskesdas) 2007 pada penduduk berumur $>10$ tahun terdapat prevalensi kurang makan buah dan sayur 93,6\%, sedangkan pada umur 10 - 14 tahun yang kurang makan sayur dan buah 93,6\%. Penduduk Sulawesi Selatan yang kurang makan buah, sayuran $93,7 \%$ ( $<5$ porsi per hari). ${ }^{6}$ Proporsi penduduk $\geq 10$ tahun yang kurang makan sayur dan buah berdasarkan Riskesdas (2013) adalah 93,5\%, hal ini menunjukkan tidak terjadi perubahan yang berarti antara data 2007 dan $2013 .{ }^{7}$

Kurang makan sayur dan buah dan asupan karbohidrat yang berlebih yang tidak dimbangi dengan aktivitas fisik dapat memicu timbulnya non communicable disease (NCD). Anak obesitas dapat mengalami penyakit NCD dan kematian antara lain seperti obstructive sleep apnea (OSA), peningkatan risiko patah tulang, hipertensi, kolesterol darah meningkat, tanda awal penyakit kardiovaskular, sindrom metabolik, dislipidemia, diabetes elitus tipe 2, resistensi insulin, sindrom ovarium polikistik, kolelitiasis dan efek psikologis.1,5 Beberapa penyakit yang terjadi pada usia dewasa sebagai dampak overweight dan obesitas pada saat anak-anak akan sangat merugikan anak. Oleh karena itu diperlukan penanganan overweight maupun obesitas sejak dini pada anak usia sekolah untuk mencegah terjadinya beberapa penyakit saat dewasa. Berdasarkan skrining awal pada 5 sekolah dasar inpres di Tamalanrea, dari 600 anak didapatkan 39 overweight dan 60 obesitas.

Untuk mengoptimalkan upaya peningkatan kesehatan anak dapat digunakan model kesehatan anak yaitu child healthcare model (CHM) adalah model pelayanan kesehatan yang diterapkan dalam keperawatan kesehatan anak pada seluruh konteks pelayanan kesehatan. Tujuannya untuk menggambarkan bahwa perawat pediatrik perlu untuk mengintegrasikan konsep promosi kesehatan dan pemeliharaan kesehatan kedalam semua aspek perawatan. ${ }^{8}$ Strategi yang dapat digunakan adalah dengan pendekatan transtheoretical model (TTM) yaitu perubahan perilaku yang membantu anak dan orangtua dalam membuat keputusan yang lebih efektif untuk mengurangi perilaku risiko masalah kesehatan pada anak overweight dan obesitas serta meningkatkan perilaku se- hat dengan menggunakan tahap perubahan yaitu action. ${ }^{9}$ Penelitian ini bertujuan membuktikan pengaruh pendekatan CHM dan TTM terhadap asupan makan anak overweight dan obesitas.

\section{Metode}

Rancangan penelitian ini menggunakan quasi-experiment, yaitu pretest and posttest with control group design. Penelitian dilaksanakan pada bulan Agustus 2013 Maret 2014 berlokasi di wilayah kecamatan Biringkanaya dan Tamalanrea, Makassar. Kelompok perlakuan diberikan intervensi pendidikan kesehatan selama 6 bulan melalui pendekatan CHM dan TTM dengan memberikan buku panduan gaya hidup sehat dan selebaran pada anak dengan berat badan berlebih sedangkan kontrol tidak diberikan intervensi, hanya berupa selebaran.

Pendekatan CHM menekankan pada upaya pencegahan yaitu perawat melakukan promosi dan pemeliharaan kesehatan tentang asupan makan yang seimbang pada anak. Sedangkan TTM adalah tahapan perubahan dalam asupan makanan sehat yang meliputi precontemplation, yaitu tidak aktif secara fisik atau tidak berniat untuk berubah dalam 6 bulan ke depan, contemplation, yaitu tidak aktif secara fisik tapi berniat menjadi aktif dalam 6 bulan ke depan, preparation, yaitu melakukan beberapa persiapan untuk berubah dalam 1 bulan sesuai pedoman yang direkomendasikan, action, yaitu melakukan tindakan yaitu kurang lebih 6 bulan, dan maintenance, yaitu melakukan pemeliharaan secara aktif lebih dari 6 bulan. Pendekatan TTM ini menggunakan tahap action selama 6 bulan yang sebelumnya anak telah melalui tahap preparation. Pendekatan kedua model ini merupakan pemberian intervensi promosi dan pemeliharaan kesehatan tentang asupan makan seimbang pada anak overweight dan obesitas selama 6 bulan yakni berada pada tahap action.

Subyek penelitian adalah anak overweight atau obesitas sekolah dasar kelas 4 - 6 yang dipilih dengan metode purposive sampling yaitu memilih sampel yang memenuhi kriteria inklusi dengan jumlah sampel sebanyak 64 orang yang terdiri dari 31 kelompok perlakuan dan 33 kelompok kontrol. Subyek bersedia dan mengisi informed consent, berjenis kelamin laki-laki dan perempuan, suku Bugis atau Makassar yang beragama muslim dan berada pada tahap action, kelas 4 - 6, anak telah kooperatif dalam mengikuti prosedur penelitian dan berdasarkan penilaian aktivitas fisik sebagai kontrol menggunakan Physical Activity Questionnaire for Older Children (PAQ-C) sesuai untuk anak usia sekolah dasar (kelas 4 - 8, sekitar usia 8 - 14 tahun). Variabel independen adalah pendekatan CHM dan TTM sedangkan variabel dependen adalah asupan makan anak. Penelitian ini telah mendapatkan persetujuan dari Komite Etik Fakultas Kedokteran Universitas Hasanuddin. 
Tabel 1. Analisis Karakteristik Responden pada Kelompok Perlakuan dan Kelompok Kontrol

\begin{tabular}{|c|c|c|c|c|c|c|}
\hline \multirow{3}{*}{ Karakteristik Responden } & \multirow{3}{*}{ Kategori } & \multicolumn{4}{|c|}{ Kelompok } & \multirow{3}{*}{ Nilai $p$} \\
\hline & & \multicolumn{2}{|c|}{ Perlakuan } & \multicolumn{2}{|c|}{ Kontrol } & \\
\hline & & n (31) & $\%$ & n (33) & $\%$ & \\
\hline \multirow[t]{2}{*}{ Jenis kelamin } & Laki-laki & 18 & 58,1 & 15 & 45,5 & 0,313 \\
\hline & Perempuan & 13 & 41,9 & 18 & 54,5 & \\
\hline \multirow[t]{2}{*}{ Pendidikan ayah } & Tinggi & 20 & 64,5 & 22 & 66,7 & 0,856 \\
\hline & Rendah & 11 & 35,5 & 11 & 33,3 & \\
\hline \multirow{2}{*}{ Pendidikan ibu } & Tinggi & 14 & 45,2 & 18 & 54,5 & 0,453 \\
\hline & Rendah & 17 & 54,8 & 15 & 45,5 & \\
\hline \multirow{2}{*}{ Pendapatan keluarga } & Tinggi & 31 & 100,0 & 32 & 97,0 & 0,329 \\
\hline & Rendah & 0 & 0 & 1 & 3,0 & \\
\hline \multirow{2}{*}{ Riwayat kegemukan orang tua } & Ada riwayat & 29 & 93,5 & 30 & 90,9 & 0,694 \\
\hline & Tidak ada riwayat & 2 & 6,5 & 3 & 9,1 & \\
\hline \multirow{2}{*}{ Riwayat kesehatan } & Keluarga berisiko & 22 & 71,0 & 27 & 81,8 & 0,306 \\
\hline & Keluarga tidak berisiko & 9 & 29,0 & 6 & 18,2 & \\
\hline \multirow[t]{2}{*}{ Struktur keluarga } & Keluarga inti & 26 & 83,9 & 22 & 66,7 & 0,112 \\
\hline & Keluarga besar & 5 & 16,1 & 11 & 33,3 & \\
\hline
\end{tabular}

Pengisian kuesioner dengan wawancara langsung, dilakukan oleh tim yang sudah dilatih. Semua sampel yang terpilih, diukur berat badan dan tinggi badannya tim terlatih sebanyak 4 orang, kemudian untuk menentukan indeks massa tubuh (IMT) anak menggunakan WHO AntrhoPlus software berdasarkan WHO 2007 untuk anak usia 5-18 tahun. Sebelum dan setelah intervensi, asupan makan anak berupa karbohidrat yang diukur menggunakan food recall. Analisis yang digunakan adalah analisis bivariat. Perbedaan asupan antara kelompok perlakuan dan kontrol setelah intervensi digunakan uji-t paired.

\section{Hasil}

Hasil penelitian menunjukkan bahwa antara kelompok perlakuan dan kelompok kontrol telah memiliki kesetaraan/homogenitas. Hasil uji homogenitas antara kelompok perlakuan dan kelompok kontrol pada jenis kelamin anak didapat nilai $\mathrm{p}=0,313$; pendidikan ayah didapat nilai $\mathrm{p}=0,856$; pendidikan ibu didapat nilai $\mathrm{p}=0,453$; pendapatan keluarga didapat nilai $\mathrm{p}=0,329$; riwayat kegemukan orang tua didapat nilai $\mathrm{p}=0,694$; riwayat kesehatan keluarga didapat nilai $\mathrm{p}=0,306$; dan status keluarga didapat nilai $\mathrm{p}=0,112$.

Hasil penelitian ini menunjukkan bahwa tidak terdapat perbedaan untuk jenis kelamin anak, pendidikan ayah, pendidikan ibu, pendapatan keluarga, riwayat kegemukan orang tua, riwayat kesehatan keluarga, dan status keluarga antara kelompok perlakuan dan kelompok kontrol (Tabel 1).

Gambar 1 dan 2 menunjukkan grafik distribusi asupan makan anak pre-post pada kelompok perlakuan. Asupan makan meliputi energi, protein, lemak, karbohidrat, vitamin $\mathrm{C}$, vitamin $\mathrm{D}$, dan serat. Asupan karbohidrat pre-post pada kelompok perlakuan yaitu asupan

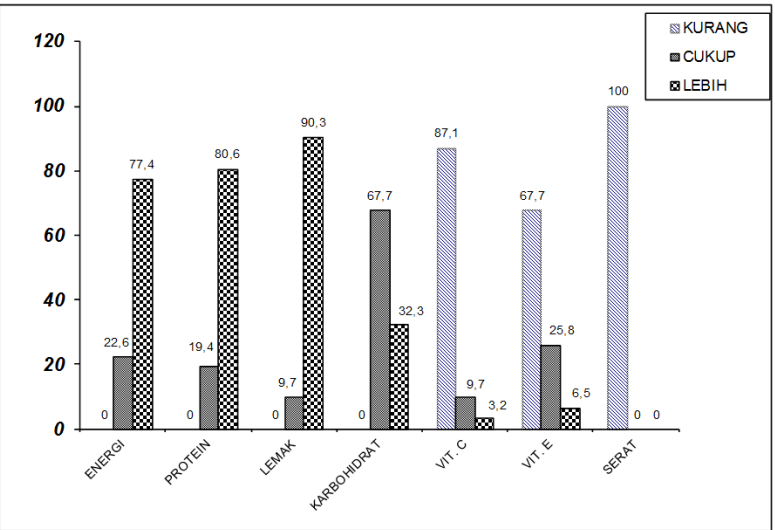

Gambar 1. Asupan Makan Anak Pre Intervensi

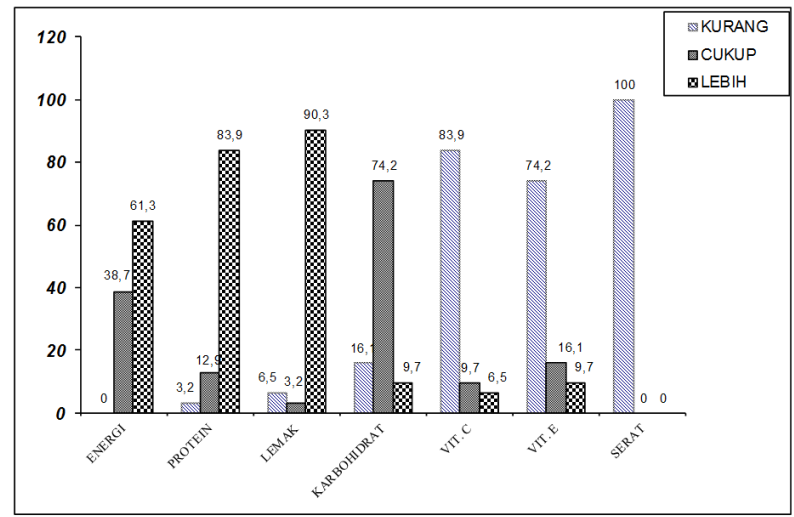

Gambar 2. Asupan Makan Anak Post Intervensi

karbohidrat yang kurang dari $0 \%$ menjadi $16,1 \%$; asupan cukup dari $67,7 \%$ menjadi $74,2 \%$; dan asupan lebih dari $32,3 \%$ menjadi $9,7 \%$. Hal ini menunjukkan terjadi penurunan asupan karbohidrat sebelum dan setelah intervensi.

Hasil uji-t paired menunjukkan rerata perubahan 
Tabel 2. Perbedaan Rerata Asupan Makan Anak Sebelum dan Setelah Intervensi antara Kelompok Perlakuan dengan Kontrol

\begin{tabular}{llllllll}
\hline Asupan Makanan & Kelompok & Pre/Post & n & Mean & SD & Perubahan Mean & Nilai p \\
\hline \multirow{2}{*}{ Karbohidrat } & \multirow{2}{*}{ Perlakuan } & Pre & 31 & 316,67 & 72,7 & $-42,20$ & 0,004 \\
& Kost & 31 & 274,47 & 56,7 & & \\
& Kontrol & Pre & 33 & 312,32 & 51,9 & $-19,02$ & 0,114 \\
& & Post & 33 & 293,30 & 37,1 & & \\
\hline
\end{tabular}

asupan karbohidrat mengalami penurunan yaitu kelompok perlakuan sebesar -42,20 dan kelompok kontrol sebesar -19,02. Penurunan asupan karbohidrat lebih tinggi pada kelompok perlakuan daripada kelompok kontrol. Hasil uji beda menunjukkan asupan karbohidrat pada kelompok perlakuan terdapat perbedaan antara sebelum dan setelah intervensi dengan nilai $\mathrm{p}=0,004$ sedangkan kelompok kontrol tidak terdapat perbedaan dengan nilai $\mathrm{p}=0,114$ (Tabel 2).

\section{Pembahasan}

Asupan karbohidrat pada anak kelompok perlakuan terdapat perbedaan sebelum dan setelah intervensi. Hal ini membuktikan ada pengaruh pendekatan CHM dan TTM terhadap asupan karbohidrat anak overweight dan obesitas. Sejalan dengan penelitian Fukuda, et al ${ }^{10}$ menunjukkan peningkatan konsumsi daging akan meningkatkan risiko obesitas sebesar 1,46 kali. Penelitian Mushtaq, et al ${ }^{11}$ menyatakan bahwa melewatkan sarapan, makan makanan cepat saji dan makanan ringan sekali atau lebih dalam seminggu berhubungan dengan overweight dan obesitas. Peran perawat dalam pendekatan CHM dan TTM melalui pendidikan kesehatan pada penelitian ini adalah memberikan contoh menu sehat seimbang untuk anak SD dan keluarga, perilaku makan yang baik serta lembar monitoring asupan makan.

Menurut Pender dalam Tomey dan Aligood, ${ }^{12}$ perilaku promosi kesehatan termasuk diet sehat, olahraga teratur dapat membangun hubungan positif. Promosi kesehatan dapat dilakukan dengan pendidikan kesehatan menggunakan berbagai metode. Penelitian Alison, et al 13 melihat hubungan antara aktivitas fisik dan komponen TTM pada usia dewasa tua dengan DM tipe 2 dan/atau penyakit kardiovaskuler. Aktivitas fisik, self-efficacy dan pro aktivitas lebih besar dalam tahap maintenance daripada tahap kontemplasi. Penelitian Baby dan Bhat yaitu intervensi multikomponen diberikan selama satu bulan pada 269 anak didapatkan $13(4,8 \%)$ adalah overweight, $7(2,6 \%)$ mengalami obesitas. Aktivitas menetap setelah jam sekolah, menonton televisi untuk durasi yang lebih lama pada hari minggu dan hari kerja, penurunan aktivitas fisik, melewatkan makan, pengaruh media dalam memilih makanan, orang tua menawarkan makanan se- bagai hadiah, seringnya mengonsumsi makanan goreng dan junk food, dan sering minum minuman berkarbonasi adalah faktor yang penting memengaruhi kejadian overweight dan obesitas. ${ }^{14}$

Penelitian pendekatan CHM dan TTM ini sejalan dengan tujuan Healthy People 2020, yaitu asupan makanan sehat dan aktivitas fisik di antara anak dan remaja yang meliputi rencana komprehensif untuk promosi kesehatan dan pencegahan penyakit. ${ }^{15}$ Menurut Barlow ${ }^{16}$ anak overweight dan obesitas serta keluarga berfokus pada gaya hidup makan yang sehat sebagai strategi pencegahan obesitas. Langkah awal yang dilakukan adalah menumbuhkan motivasi anak untuk ingin menurunkan berat badan setelah anak mengetahui berat badan ideal yang disesuaikan dengan IMT.

Selain asupan dan perilaku makan anak dikontrol, penting juga untuk mengendalikan aktivitas fisik anak. Mempromosikan kesehatan perilaku (diet dan olahraga) atau kegiatan santai (menonton televisi atau bermain video game) akan berubah pada anak dan keluarga dari pengalaman dan budaya keluarga yang tidak mendukung menjadi praktik mandiri bagi keluarga dalam mengendalikan gaya hidup sehat pada anak obesitas. Studi Dennison, et al ${ }^{17}$ bahwa ada hubungan menonton TV dengan risiko kejadian overweight pada anak prasekolah. TV di dalam kamar anak adalah kondisi pencetus yang kuat terhadap peningkatan risiko overweight. Hasil studi Tremblay dan Willms ${ }^{18}$ menunjukkan bahwa aktivitas fisik dan dan sedentary behaviour, berhubungan dengan anak overweight. Menurut Hoyo-Barbolla, et al ${ }^{19}$ tahapan perubahan yaitu perubahan asupan buah, sayur dan ikan yang lemah hubungannya, keseimbangan putusan (decision balance) dan self-efficacy hubungannya lebih kuat.

Beberapa faktor gaya hidup yang penting pada anak usia sekolah adalah tidur $9-10$ jam setiap hari, makan 3 kali sehari pada waktu yang teratur dengan diet tinggi serat, menghindari fast food dan minuman bersoda, sarapan pagi tiap hari, melakukan latihan aerobik/aktivitas fisik minimal 60 menit setiap hari, menonton televisi, bermain game atau komputer $\leq 2$ jam per hari, dan menjaga berat badan ideal. ${ }^{16,20}$ Melalui intervensi pendidikan kesehatan dengan pendekatan CHM dan TTM selama 6 bulan dapat mempengaruhi asupan karbohidrat 
pada anak overweight dan obesitas yaitu terjadi penurunan sehingga dapat mencegah dampak penyakit saat anak dewasa, meningkatkan kesehatan dan kualitas hidup anak. Setiap perawat memiliki tanggung jawab termasuk promosi kesehatan dan pemeliharaan kesehatan dengan memperhatikan budaya keluarga dalam merawat anak overweight dan obesitas dengan menggunakan strategi perubahan perilaku.

\section{Kesimpulan}

Penelitian ini menunjukkan bahwa terdapat perbedaan rata-rata signifikan perubahan asupan karbohidrat pada kelompok perlakuan pada siswa kelas 4 - 6 SD Inpres Tamalanrea Makassar 2014. Terdapat pengaruh pendekatan CHM dan TTM terhadap asupan karbohidrat anak overweight dan obesitas.

\section{Saran}

Penyuluhan rutin tentang upaya penurunan asupan energi, karbohidrat dan lemak serta peningkatan asupan vitamin dan serat pada siswa sekolah dasar dan pelatihan bagi guru di sekolah perlu untuk menjaga asupan makan yang sehat seimbang. Promosi kesehatan melalui pendidikan kesehatan dapat menggunakan pendekatan model dan media lain seperti elektronik.

\section{Daftar Pustaka}

1. World Health Organization (WHO). Population-based prevention strategies for childhood obesity: report of a WHO forum and technical meeting. Geneva: Department of Child and Adolescent Health and Development; 2010.

2. Centers for Disease Control and Prevention (CDC) [homepage on internet]. Trends in the prevalence of obesity, dietary behaviours, and weight control practices national YRBS: 1991-2011. 2011 [cited 2013 Apr 8]. Available from: www.cdc.gov/yrbss.

3. Hamam H. Gizi lebih sebagai tantangan baru dan implikasinya terhadap kebijakan pembangunan kesehatan nasional. The Indonesian Journal of Clinical Nutrition. 2004; 1 (2): 51-8.

4. Wong DL, Eaton MH, Wilson D, Winkelstein ML, Schwartz P. Wong's essentials of pediatric nursing. 6th Edition. Missouri: Mosby Inc; 2009.

5. Gupta N, Goel K, Shah P, Misra A. Childhood obesity in developing countries: epidemiology, determinants, and prevention. Endocrine Reviews (EndoJournals). 2012; 33 (1): 48-70.

6. Badan Penelitian dan Pengembangan Kesehatan. Riset kesehatan dasar (Riskesdas) tahun 2007. Jakarta: Kementerian Kesehatan Republik
Indonesia; 2007.

7. Badan Penelitian dan Pengembangan Kesehatan. Riset kesehatan dasar (Riskesdas) tahun 2013. Jakarta: Kementerian Kesehatan Republik Indonesia; 2013.

8. Ball J, Bindler R. The Bindler-Ball healthcare model: a new paradigm for health promotion. Pediatric Nursing. 2007; 33 (2): 121-6.

9. Prochaska JO, Butterworth S, Redding CA, Burden V, Perrin N, Leo M, et al. Initial efficacy of BMI, TTM tailoring and HRI's with multiple behaviors for employee health promotion. Preventive Medicine. 2008; 46 (3): 226-31.

10. Fukuda S, Takeshita T, Morimoto K. Obesity and lifestyle. Asian Medical Journal. 2001; 44: 97-102.

11. Mushtaq MU, Gull S, Mushtaq K, Shahid U, Shad MA, Akram J. Dietary behaviors, physical activity and sedentary lifestyle associated with overweight and obesity, and their socio-demographic correlates, among Pakistani primary school children. International Jounal of Behavioral Nutrition and Physical Activity. 2011; 8: 130.

12. Tomey AM, Alligood MR. Nursing theorist and their work. Missouri: Mosby Inc; 2006.

13. Alison K, Freya M, Nikki W. Application of the transtheoretical model to physical activity in older adults with type 2 diabetes and/or cardiovascular disease. Psychology of Sport and Exercise (Elsevier). 2010; 11: $320-4$.

14. Baby N, Bhat HV. A study to evaluate the effectiveness of multicomponent intervention on lifestyle practices, body fat and self esteem of obese/overweight school children in selected English medium schools of Udupi district, Karnataka. International Journal of Nursing Education. 2010; 2 (2): 9-12.

15. Centers for Disease Control and Prevention (CDC). School health guidelines to promote healthy eating and physical activity. Morbidity and Mortility Weekly Report (MMWR). 2011; 60 (5): 1-53.

16. Barlow SE. Expert Committee recommendations regarding the prevention, assessment, and treatment of child and adolescent overweight and obesity: Summary report, Pediatrics. 2007; 120 (Suppl. 4): S164-92.

17. Dennison BA, Erb TA, Jenkins PL. Television viewing and television in bedroom associated with overweight risk among low-income preschool children. Pediatrics. 2002; 109: 1028-35.

18. Tremblay MS, Willms JD. Is the Canadian childhood obesity epidemic related to physical inactivity?. International Journal of Obesity. 2003; 27: $1100-5$.

19. Hoyo-Barbolla E, Kukafka R, Arredondo MT, Ortega M. A new perspective in the promotion e-health. In: Hasman, ed. Technologies for better health in aging societies. Spain: IOS Press; 2006.

20. Guyton AC, Hall JE. Textbook of medical physiology. 11th ed. Philadelphia: Elsevier Saunders; 2007. 